\title{
Annual variability and regulation of methane and sulfate fluxes in Baltic Sea estuarine sediments
}

\author{
Joanna E. Sawicka and Volker Brüchert \\ Department of Geological Sciences, Stockholm University, Stockholm, 10691, Sweden \\ Correspondence to: Volker Brüchert (volker.bruchert@geo.su.se)
}

Received: 29 June 2016 - Published in Biogeosciences Discuss.: 13 July 2016

Revised: 16 December 2016 - Accepted: 23 December 2016 - Published: 23 January 2017

\begin{abstract}
Marine methane emissions originate largely from near-shore coastal systems, but emission estimates are often not based on temporally well-resolved data or sufficient understanding of the variability of methane consumption and production processes in the underlying sediment. The objectives of our investigation were to explore the effects of seasonal temperature, changes in benthic oxygen concentration, and historical eutrophication on sediment methane concentrations and benthic fluxes at two type localities for open-water coastal versus eutrophic, estuarine sediment in the Baltic Sea. Benthic fluxes of methane and oxygen and sediment pore-water concentrations of dissolved sulfate, methane, and ${ }^{35} \mathrm{~S}$-sulfate reduction rates were obtained over a 12-month period from April 2012 to April 2013. Benthic methane fluxes varied by factors of 5 and 12 at the offshore coastal site and the eutrophic estuarine station, respectively, ranging from $0.1 \mathrm{mmol} \mathrm{m}^{-2} \mathrm{~d}^{-1}$ in winter at an open coastal site to $2.6 \mathrm{mmol} \mathrm{m}^{-2} \mathrm{~d}^{-1}$ in late summer in the inner eutrophic estuary. Total oxygen uptake (TOU) and ${ }^{35} \mathrm{~S}$-sulfate reduction rates (SRRs) correlated with methane fluxes showing low rates in the winter and high rates in the summer. The highest pore-water methane concentrations also varied by factors of 6 and 10 over the sampling period with the lowest values in the winter and highest values in late summerearly autumn. The highest pore-water methane concentrations were $5.7 \mathrm{mM}$ a few centimeters below the sediment surface, but they never exceeded the in situ saturation concentration. Of the total sulfate reduction, $21-24 \%$ was coupled to anaerobic methane oxidation, lowering methane concentrations below the sediment surface far below the saturation concentration. The data imply that bubble emission likely plays no or only a minor role in methane emissions in these sediments. The changes in pore-water methane con-
\end{abstract}

centrations over the observation period were too large to be explained by temporal changes in methane formation and methane oxidation rates due to temperature alone. Additional factors such as regional and local hydrostatic pressure changes and coastal submarine groundwater flow may also affect the vertical and lateral transport of methane.

\section{Introduction}

The world's estuaries have been suggested to emit between 1.8 and $6.6 \mathrm{TgCH}_{4} \mathrm{yr}^{-1}$ to the atmosphere (Borges and Abril, 2011; Amouroux et al., 2002; Marty et al., 2001; Middelburg et al., 2002; Sansone et al., 1999; Upstill-Goddard et al., 2000), a considerable portion of the estimated total oceanic emissions of 10-30 Tg CH $4 \mathrm{yr}^{-1}$ (Judd, 2004; Etiope et al., 2008; Kirschke et al., 2013). Like other globally upscaled estimates of emissions, these estimates also have considerable uncertainties. In the case of estuaries, a major cause of the uncertainty is that there are relatively few spatially and temporally resolved measurements of anaerobic carbon degradation in sediments and there are relatively few measurements of methane fluxes from sediments. In estuarine waters methane can be derived from underlying anoxic sediments or transported laterally due to freshwater or sewage discharge or seepage of methane-rich groundwater. It can also be derived from near-shore aquatic plants (Borges and Abril, 2011). The amount of sedimentary methane production in estuaries is a function of organic matter availability, bottom-water oxygen concentrations, and the salinity of the estuary. Methane production is generally greater in lowsalinity estuaries because of lower sulfate availability for promoting bacterial sulfate reduction (Borges and Abril, 2011). 
Methane fluxes from estuarine sediments are characterized by significant spatial and temporal variability (Borges and Abril, 2011). Temporal patterns show that concentrations and fluxes of $\mathrm{CH}_{4}$ are generally higher in the warmer season and low in the colder season (Crill et al., 1983; Martens and Klump, 1984; Musenze et al., 2014; Reindl and Bolałek, 2014). Notably, very few studies have considered $\mathrm{CH}_{4}$ fluxes in high-latitude environments during snow- and ice-covered periods. While shallow systems within the tidal range derive a significant amount of the methane flux from ebullition (Martens and Klump, 1984), groundwater discharge, tidal pumping, and transport by aquatic plants (Middelburg et al., 2002; Kristensen et al., 2008), the transport from deeper systems such as fjords and fjärds is thought to occur largely by molecular diffusion (Abril and Iversen, 2002; Sansone et al., 1998).

Globally more than $90 \%$ of methane produced in marine sediments is estimated to be oxidized by the anaerobic oxidation of methane (AOM), mostly in the sulfate-methane transition zone (Knittel and Boetius, 2009; Martens and Berner, 1974; Jørgensen and Parkes, 2010). It is not known how much methane is oxidized by AOM in estuarine sediments. In addition, up to $90 \%$ of the remaining methane that reaches the sediment surface may be oxidized aerobically at the sediment surface or in the water column (Reeburgh, 2007). However, methane concentrations in estuarine waters are almost always higher than the atmospheric equilibrium concentration (Bange et al., 2010), indicating that microbial oxidation processes and physical exchange with the atmosphere in estuaries are relatively inefficient in removing methane. Despite its obvious importance, only a few studies have specifically addressed anaerobic oxidation of methane by sulfate and aerobic oxidation in estuarine environments (e.g., Treude et al., 2005a; Thang et al., 2013).

The objective of this study was therefore to further elucidate mechanisms behind temporal variability of methane fluxes in a high-latitude coastal and estuarine environment with strong seasonal temperature variability, winter ice cover, and a variable degree of eutrophication stress. These data fill an important gap in global inventories of nearshore sediment methane dynamics and help improve our mechanistic understanding of methane emissions from marine near-shore systems. We determined pore-water concentrations of methane and sulfate, measured sulfate reduction rates with the ${ }^{35} \mathrm{~S}$ sulfate tracer method, and conducted core incubations to determine benthic fluxes of methane and oxygen at two deep stations of a low-salinity Baltic Sea estuary inside and at the opening of the estuary to the Baltic. Investigations were carried out over four seasons to capture the annual variability of chemical and biological conditions at the sediment surface and their influence on methane dynamics.

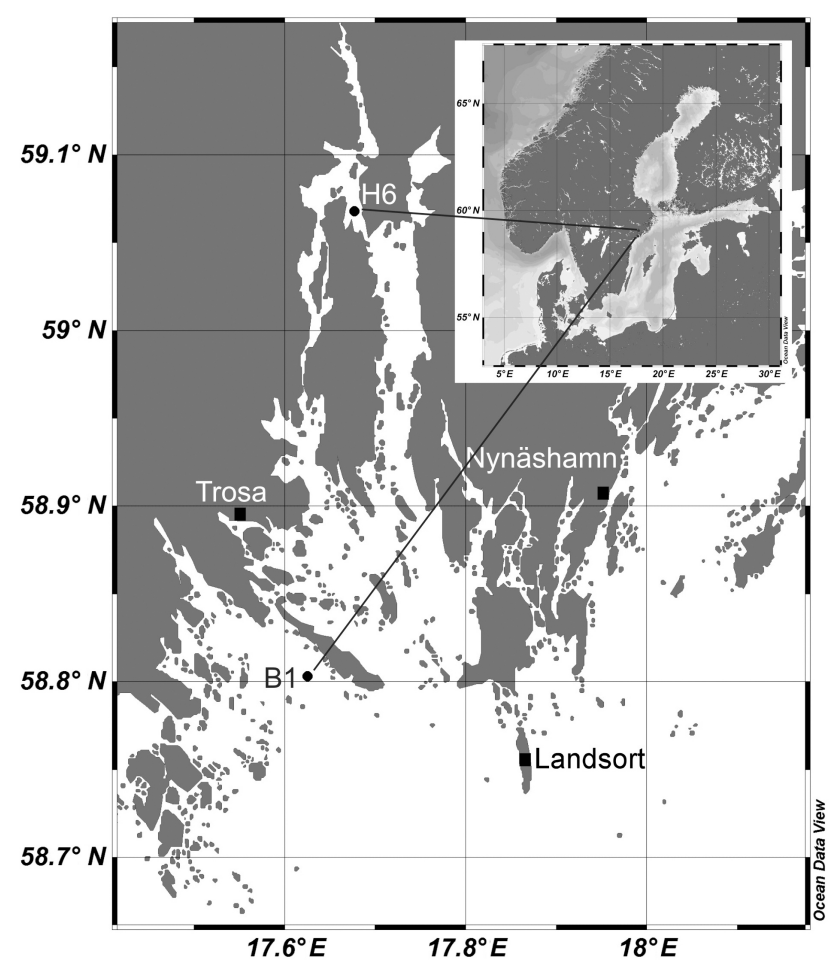

Figure 1. Location of sampling sites in Himmerfjärden, Stockholm archipelago, Sweden. Detailed studies were conducted at two sites: an open water site (station B1) and in the inner part of the estuary (station H6).

\section{Materials and methods}

\subsection{Site description}

Himmerfjärden (Fig. 1) is a fjord-type estuary with a surface area of $174 \mathrm{~km}^{2}$, a volume of $2968 \times 10^{6} \mathrm{~m}^{3}$, and a N-S bottom-water salinity gradient increasing from $5.5 \%$ in the inner part to $7.0 \%$ at the opening to the Baltic. It is morphologically characterized by four basins, divided by sills and has a low flushing rate of about $0.025 \mathrm{day}^{-1}$ (Savage et al., 2010). The freshwater discharge is small compared to the exchange with the open Baltic and was estimated to be $23 \mathrm{~m}^{3} \mathrm{~s}^{-1}$ on average in 2012, comprising land runoff and precipitation (30 and $21 \%$, respectively), outflow from Lake Mälaren from the north (19\%) and the river Trosaån $(23 \%)$, and discharge from a sewage treatment plant $(6 \%)$ (Larsson et al., 2012). The sewage treatment plant, built in the early 1970s, treats sewage water from ca. 314000 inhabitants of the southern Stockholm metropolitan area, and its inorganic effluent is discharged mainly in the form of inorganic nitrogen and phosphorus to the inner basins (Savage et al., 2010). In 2012, the sewage treatment contributed $45 \%$ to the total phosphorus and $57 \%$ to the total inorganic nitrogen discharge to the northern Himmerfjärden area (Larsson et al., 2012); it also discharged 1676 tons of carbon (measured as chemical oxygen demand COD) (Stridh, 2012). 
The estuary undergoes thermohaline stratification during late summer and autumn, especially in the inner part, which experiences regular seasonal bottom-water hypoxia. The tidal range is low (few $\mathrm{cm}$ ) and relatively cold bottom waters (1.5$9^{\circ} \mathrm{C}$ ) dominate throughout the year. Water level can vary annually by about $50 \mathrm{~cm}$ depending on local wind and hydrographic conditions. Late summer-early fall bottom-water hypoxia has also occasionally been reported for the outer basins of the estuary when winds were weak and circulation was inhibited (Elmgren and Larsson, 1997). Sedimentation areas in Himmerfjärden can be divided into accumulation and transport bottoms (Jonsson et al., 2003). About $21 \%$ of the sediment surface in Himmerfjärden is classified as accumulation bottoms of particulate material and receives 3.3-9 mol C m${ }^{-2} \mathrm{yr}^{-1}$ (Thang et al., 2013; Karlsson et al., 2010).

Bottom-water and sediment samples were taken from a station in the inner part of Himmerfjärden, station H6, and from a station located outside the estuary, station B1 (Fig. 1). Samples were collected in April 2012, August 2012, and October 2012 with the research vessel R/V Limanda and in February 2013 with the ice-breaking research vessel R/V Aurelia. In addition, in April 2013 whole-core incubations were performed to determine methane and oxygen fluxes to record a full year of seasonal variability. Station B1 has soft, olive grey, muddy sediment with a $1-2 \mathrm{~cm}$ thick rusty brown surface layer that was present year round, while the sediment at station H6 is soft, laminated black mud with a 1-2 mm thin brown surface layer that occurred only during the winter and spring. Sediment accumulation rates range from $0.98 \mathrm{~cm} \mathrm{yr}^{-1}$ in the innermost part of the estuary to $0.77 \mathrm{~cm} \mathrm{yr}^{-1}$ in the outer part of the estuary (Thang et al., 2013).

\subsection{Sample collection}

Sediments with well-preserved sediment surfaces were collected with a Multi-Corer in acrylic tubes $(9.5 \mathrm{~cm}$ diameter) to $40 \mathrm{~cm}$ depth to determine ${ }^{35} \mathrm{~S}$-sulfate reduction rates, porosity, and the pore-water constituents methane and sulfate. Additional cores were collected for sediment core incubations. Pore-water methane samples were immediately collected onboard the research vessels R/V Limanda and the ice-class vessel R/V Aurelia from the cores as described below. The other cores were capped with rubber stoppers, transported to the marine laboratory on the island of Askö within $90 \mathrm{~min}$, and kept cold at bottom-water temperature for later experiments and subsampling. In February 2013, ice partially covered station B1 and there was complete ice cover at station H6, making sampling only possible after ice breaking. For whole-core incubations, $30 \mathrm{~L}$ of bottom water was collected with a $5 \mathrm{~L}$ Hydro-Bios bottle and kept cold until the experiments were conducted. Temperature, salinity, and oxygen concentrations were determined with a handheld WTW oxygen meter directly in the water overlying the sediment cores.

\subsection{Organic carbon concentrations and porosity}

Concentrations of organic carbon were determined for the topmost centimeter of sediment on freeze-dried sediment with a Fisons $\mathrm{CHN}$ elemental analyzer after treatment with $1 \mathrm{M} \mathrm{HCl}$ to remove inorganic carbon. Water content (\%) was determined by drying $5 \mathrm{~mL}$ of sediment at $105^{\circ} \mathrm{C}$ and calculating the percent loss after drying.

\subsection{Methane analysis}

Samples for methane were collected directly through the side of taped, predrilled core liners and taken in $2 \mathrm{~cm}$ intervals minutes after the core was retrieved on deck. The core sampling method used in this study permitted complete sampling and preservation of porewater methane within $5 \mathrm{~min}$ after the core was on deck. Under these circumstances, loss of methane due to gas loss was low and methane concentrations could be determined for porewaters that were far above the saturation limit at $1 \mathrm{~atm}$ for the salinity and temperature range of the bottom water (between 1.9 and $2.4 \mathrm{mM}$ ). A sediment sample of $2.5 \mathrm{~mL}$ was taken with a $3 \mathrm{~mL}$ cutoff syringe. The sample was transferred to a $20 \mathrm{~mL}$ serum vial containing $5 \mathrm{~mL} 5 \mathrm{M} \mathrm{NaCl}$ and was immediately closed with a thick septum and an aluminum crimp seal (Thang et al., 2013). For analysis, the sample was shaken and $5 \mathrm{~mL}$ of brine was injected into a sample vial to displace $5 \mathrm{~mL}$ of gas out of a vial into the syringe. The $\mathrm{CH}_{4}$ measurements were carried out on a gas chromatograph (GC) with a flame ionization detector (FID) (SRI 8610C) after separation on a $1 \mathrm{~m}$ Porapak Q precolumn before a $3 \mathrm{~m}$ Hayesep D column with $\mathrm{N}_{2}$ as carrier gas. $\mathrm{CH}_{4}$ standards 100, 1000, and 10000 ppm (Air Liquide) were used for calibration.

The concentration of methane (mM) of a sample was calculated as follows:

$\mathrm{CH}_{4}(\mathrm{mM})=\frac{\mathrm{CH}_{4 \mathrm{hsp}} \cdot V_{\mathrm{hsp}}}{1000 \cdot 24.148 \cdot V_{\text {sed }} \cdot \rho}$,

where $\mathrm{CH}_{4 \text { hsp }}$ is the concentration of methane in the headspace of the sample vial (ppm), $V_{\mathrm{hsp}}$ is the volume of the headspace $(\mathrm{L}), V_{\text {sed }}$ is the volume of the sediment sample (L), $\rho$ is sediment porosity, and $24.148\left(\mathrm{~L} \mathrm{~mol}^{-1}\right)$ is the molar volume of gas at standard pressure $100 \mathrm{kPa}$ and $298 \mathrm{~K}$. The reproducibility of the method was tested at a station in the archipelago that is not part of this study by replicating methane sampling on multiple sediment cores. Concentrations in multiple cores deviated by about $15 \%$.

\subsection{Sulfate concentration}

Porewater samples for sulfate concentration measurements were obtained using rhizones (Atlas Copco Welltech) (Seeberg-Elverfeldt et al., 2005). Rhizones were treated for 
$2 \mathrm{~h}$ in $2 \mathrm{M} \mathrm{HCl}$, followed by two rinses with deionized water for $2 \mathrm{~h}$ and final storage in deionized water. Rhizones were connected to $10 \mathrm{~mL}$ disposable plastic syringes via threeway luer lock stopcocks and were inserted in $1 \mathrm{~cm}$ intervals through tight-fitting, predrilled holes in the liner of the sediment cores. The first milliliter of pore water was discarded from the syringe. No more than $2 \mathrm{~mL}$ was collected from each core to prevent cross-contamination of adjacent intervals (Seeberg-Elverfeldt et al., 2005). Sulfate concentrations were determined with a Dionex System IC 20 ion chromatograph. The detection limit for sulfate after 20 -fold dilution to reduce the chloride peak size was $100 \mu \mathrm{M}$.

\section{$2.6{ }^{35} \mathrm{~S}$-sulfate reduction rates}

To determine bacterial sulfate reduction rates (SRRs), sediment cores were subsampled in $40 \mathrm{~cm}$ long $28 \mathrm{~mm}$ diameter cores with $1 \mathrm{~cm}$ spaced silicon-sealed predrilled small holes on the side for injections. For the incubation, the whole-core incubation method by Jørgensen (1978) was used. ${ }^{35} \mathrm{SO}_{4}^{2-}$ tracer solution was diluted in a $6 \% \mathrm{NaCl}$ solution containing $0.5 \mathrm{mM} \mathrm{SO}_{4}^{2-}$. Of the tracer solution, $2.5 \mu \mathrm{L}(50 \mathrm{kBq})$ was injected through the predrilled holes. The cores were then capped and sealed in plastic wrap foil and incubated for $8 \mathrm{~h}$ at the respective bottom-water temperatures. After this time, the incubations were stopped by sectioning the core in $1 \mathrm{~cm}$ intervals to $5 \mathrm{~cm}$ depth and in $2 \mathrm{~cm}$ intervals below this depth to the bottom of the core. Sediment sections were transferred to $50 \mathrm{~mL}$ plastic centrifuge tubes containing $20 \mathrm{~mL}$ zinc acetate $(20 \% v / v)$ and were shaken vigorously and frozen. The total amount of ${ }^{35} \mathrm{~S}$-labeled reduced sulfur (TRIS) was determined using the single-step cold chromium distillation method by Kallmeyer et al. (2004). TRIS and supernatant sulfate were counted on a TriCarb 2095 Perkin Elmer scintillation counter. The sulfate reduction rate was calculated using the following equation (Jørgensen, 1978):

${ }^{35} \mathrm{SRR}=\left(\frac{\mathrm{TRI}^{35} \mathrm{~S}}{\left({ }^{35} \mathrm{SO}_{4}^{2-}+\mathrm{TRI}^{35} \mathrm{~S}\right)}\right) \cdot 1.06 \cdot \mathrm{SO}_{4}^{2-} \cdot \rho \cdot 1 / t$,

where $\mathrm{SO}_{4}^{2-}$ is the pore-water sulfate concentration corrected for porosity $\rho$, TRI ${ }^{35} \mathrm{~S}$ and ${ }^{35} \mathrm{SO}_{4}^{2-}$ are the measured counts (cpm) of total reduced inorganic sulfur species and sulfate, respectively, 1.06 is a correction factor accounting for the isotope discrimination of ${ }^{35} \mathrm{~S}$ against ${ }^{32} \mathrm{~S}$-sulfate, and $t$ is the incubation time. The sulfate reduction rate is reported as $n m o l \mathrm{~cm}^{-3} \mathrm{day}^{-1}$. Generally, when enough cores were available ${ }^{35}$ SRRs were measured on replicate cores for all depth intervals. The detection limit of the rate measurements accounting for distillation blanks and radioactive decay of ${ }^{35} \mathrm{~S}$ between experiment and laboratory workup was $0.1 \mathrm{nmol} \mathrm{cm}^{-3} \mathrm{day}^{-1}$.

\subsection{Whole-core sediment incubations}

In order to account for the total benthic exchange of oxygen and methane by advection, diffusion, bioirrigation, and bioturbation, four intact cores with undisturbed sediment surfaces and clear overlying water were subsampled in the laboratory in acrylic tubes (i.d. $6.2 \mathrm{~cm}$, height $25 \mathrm{~cm}$ ) retaining about $10 \mathrm{~cm}$ of the overlying water. The sediment height in the tubes was approximately $10 \mathrm{~cm}$. The cores were incubated in a $40 \mathrm{~L}$ incubation tank filled with bottom water from the same station. Before the incubation the overlying water in the cores was equilibrated with bottom water in the tank. The overlying water in the cores was stirred by small magnetic bars mounted in the core liners and driven by an external magnet at $60 \mathrm{rpm}$. The cores were preincubated and uncapped for $6 \mathrm{~h}$ and then subsequently capped and incubated for a period of 6 to $12 \mathrm{~h}$ depending on the initial oxygen concentration in the bottom water.

\subsubsection{Total oxygen uptake}

Oxygen sensor spots (Firesting oxygen optode, Pyro Science $\mathrm{GmbH}$, Germany) with a sensing surface of $5 \mathrm{~mm}$ diameter were attached to the inner wall of two incubation cores (diameter $5.5 \mathrm{~cm}$ ). The sensor spots were calibrated against $\mathrm{O}_{2}$-saturated bottom water and oxygen-free water following the manufacturer's guidelines accounting for temperature and salinity of the incubation water. Measurements were performed with a fiber-optic cable connected to a spot adapter fixed at the outer core liner wall at the spot position. The $\mathrm{O}_{2}$ concentration was continuously logged during incubations. Sediment total oxygen uptake (TOU) rates were computed by linear regression of the $\mathrm{O}_{2}$ concentration over time.

\subsubsection{Benthic methane fluxes}

Benthic methane fluxes were determined from discrete water samples directly above the sediment-water interface and collected without headspace in $12 \mathrm{~mL}$ Exetainers (Labco, Wycombe, UK) prefilled with $50 \mu \mathrm{L}$ of $50 \% \mathrm{ZnCl}_{2}$. Samples were collected at the beginning (time zero) and the end of the incubation (time final), usually after $24 \mathrm{~h} . \mathrm{CH}_{4}$ concentrations were determined using the headspace equilibration technique (Kampbell et al., 1989) by replacing $3 \mathrm{~mL}$ of the water in the Exetainers with high-purity helium gas at atmospheric pressure. The Exetainers were then shaken at $400 \mathrm{rpm}$ on a shaking table for $60 \mathrm{~min}$ to allow the gas to equilibrate between the headspace and the liquid phase and were left to rest for half an hour. After equilibration $2.5 \mathrm{~mL}$ of $\mathrm{NaCl}$ brine was injected into an Exetainer to force the gas samples into an injection syringe while maintaining the headspace pressure. The samples were injected onto a $1 \mathrm{~mL}$ injection loop of a gas chromatograph (SRI 8610C) with a FID detector using $\mathrm{N}_{2}$ as the carrier gas. $\mathrm{CH}_{4}$ standards 5, 100, and $1000 \mathrm{ppm}$ (Air Liquide) were used to construct a 
Table 1. Main site characteristics of the sampling stations.

\begin{tabular}{llrrrrr}
\hline Station & $\begin{array}{l}\text { Sampling } \\
\text { time }\end{array}$ & $\begin{array}{r}\text { Water } \\
\text { depth }(\mathrm{m})\end{array}$ & $\begin{array}{r}\text { Temperature } \\
\left({ }^{\circ} \mathrm{C}\right)\end{array}$ & $\begin{array}{r}\text { Bottom-water } \\
\text { salinity }(\%)\end{array}$ & $\begin{array}{r}\text { Bottom-water } \\
\text { oxygen }(\mu \mathrm{M})\end{array}$ & $\begin{array}{r}\text { Surface organic } \\
\text { carbon }(\%)\end{array}$ \\
\hline $\mathrm{B} 1$ & April 2012 & 41 & 2.4 & 6.5 & 160 & 6.0 \\
$58^{\circ} 48^{\prime} 18^{\prime \prime} \mathrm{N}$ & August 2012 & & 6.9 & 7.0 & 260 & 5.2 \\
$17^{\circ} 37^{\prime} 52^{\prime \prime} \mathrm{E}$ & October 2012 & & 6.8 & 7.0 & 224 & 5.1 \\
& February 2013 & & 3.4 & 7.0 & 380 & 5.0 \\
\hline $\mathrm{H} 6$ & April 2012 & 39.5 & 1.8 & 5.9 & 40 & 4.6 \\
$59^{\circ} 04^{\prime} 08^{\prime \prime} \mathrm{N}$ & August 2012 & & 6.7 & 6.4 & 150 & 5.1 \\
$17^{\circ} 40^{\prime} 63^{\prime \prime} \mathrm{E}$ & October 2012 & & 9.4 & 6.5 & 191 & 5.2 \\
& February 2013 & & 1.8 & 5.4 & 300 & 4.7 \\
\hline
\end{tabular}

calibration curve. The partial pressure of $\mathrm{CH}_{4}$ in the equilibrated headspace and water was calculated using the solubility coefficient $\beta$ for $\mathrm{CH}_{4}$ using the salinity of the bottom water at the respective sample time (Table 1) (Wilhelm et al., 1977), gas constant $R\left(8.314 \mathrm{~L} \mathrm{kPa} \mathrm{mol}^{-1} \mathrm{~K}^{-1}\right)$, air pressure $P(\mathrm{kPa})$, headspace gas concentration $\mathrm{CH}_{4 \mathrm{hsp}}$ (nmol), headspace volume $(0.003 \mathrm{~L})$, water volume in the Exetainer $(0.009 \mathrm{~L})$, and laboratory temperature $T(293 \mathrm{~K})$ according to

$$
\mathrm{CH}_{4}(\mathrm{nM})=\left(\mathrm{CH}_{4 \mathrm{hsp}}+\beta \mathrm{CH}_{4 \mathrm{hsp}}\right) \cdot P / R T \text {. }
$$

Fluxes $(J)$ of $\mathrm{CH}_{4}\left(\mathrm{mmol} \mathrm{m}^{-2} \mathrm{~d}^{-1}\right)$ during the whole core sediment incubations were calculated according to

$J=\left(\mathrm{CH}_{4}\right.$ start $-\mathrm{CH}_{4}$ end $) / t \cdot V / A$,

where $\mathrm{CH}_{4}$ start and $\mathrm{CH}_{4}$ final represent the end and start concentrations in $\mathrm{mmol} \mathrm{m}^{-3}, V$ is headspace volume $\left(\mathrm{m}^{3}\right), A$ is the surface area of the incubation core $\left(\mathrm{m}^{2}\right)$, and $t$ is the incubation time (days).

\subsection{Diffusive flux calculations}

Diffusive fluxes of methane and sulfate were estimated from the pore-water gradients of methane and sulfate for the sediment surface and the sulfate-methane transition zone. Sediment cores at station B1 showed occasional burrows from deposit feeders in the topmost $2 \mathrm{~cm}$ of sediment, whereas sediment at station H6 was largely devoid of macro- and meiofauna. Since only one sample was taken from the topmost $2 \mathrm{~cm}$, quantitative depth-related effects of bioturbation cannot be accounted for in this analysis and upward diffusive transport of methane was assumed as the dominant transport pathway. Fluxes were estimated using Fick's first law of diffusion:

$J=D_{\mathrm{s}} \frac{\mathrm{d} C}{\mathrm{~d} x}$,

assuming that flux was dominated by molecular diffusion, where $\mathrm{d} C$ is the change in concentration of dissolved sulfate $(\mathrm{mM})$ or methane $(\mathrm{mM})$ over a depth interval $\mathrm{d} x$ (cm), and $D_{\mathrm{s}}$ is the sediment diffusion coefficient calculated for the bottom-water temperature and salinity according to Boudreau (1996). $D_{\mathrm{s}}$ was recalculated from the molecular diffusion coefficient $D_{o}$ for sulfate and methane according to Iversen and Jørgensen (1994). Since the resolution of the pore-water methane analysis was $2 \mathrm{~cm}$, concentration changes below this resolution could not be resolved. This could lead to an overestimation of the flux across the sediment surface, e.g., due to aerobic methane oxidation in the topmost millimeter of sediment. Similar effects may occur in the sulfate-methane transition zone.

\section{Results}

\subsection{Bottom-water temperature, dissolved oxygen, sediment organic carbon}

Over the observation period April 2012-February 2013 bottom-water salinity varied between 6.5 and $7.0 \%$ at station $\mathrm{B} 1$ and 5.4 and $6.5 \%$ at station H6 (Table 1), while bottomwater temperatures ranged from 2.4 to $6.9^{\circ} \mathrm{C}$ for station B1 and 1.8 to $9.4^{\circ} \mathrm{C}$ for station H6. The lowest and highest bottom-water oxygen concentrations measured were $160 \mu \mathrm{M}$ for station B1 and $40 \mu \mathrm{M}$ for station H6 in April 2012, and 300 and $380 \mu \mathrm{M}$ for station B1 and station H6 in February 2013, respectively. Surface-sediment organic carbon concentrations were similar at the two stations, ranging between 4.6 and $5.2 \%$ at station $\mathrm{B} 1$ and 5.0 and $6.0 \%$ at station $\mathrm{H} 6$ over the observation period.

\subsection{Methane and sulfate concentrations}

At both stations, the measured methane concentrations never exceeded the solubility limit for methane calculated for the in situ pressure, which ranged from 9.6 to $11.9 \mathrm{mM}$ during the different sampling periods. At station B1, the highest methane concentrations in the sediment cores were recorded in October 2012, when they reached $0.9 \mathrm{mM}$ (Fig. 2a-d). Surprisingly, the lowest methane concentrations were recorded in August 2012. This was possibly due to drift of the ves- 
Table 2. Summary of $\mathrm{CH}_{4}$ and $\mathrm{SO}_{4}^{2-}$ fluxes, depth-integrated ${ }^{35} \mathrm{SRR}$, and total oxygen uptake (TOU).

\begin{tabular}{|c|c|c|c|c|c|c|c|c|}
\hline \multirow[t]{2}{*}{ Station } & \multirow{2}{*}{$\begin{array}{l}\text { Sampling } \\
\text { time }\end{array}$} & \multicolumn{7}{|c|}{ Flux $\left(\mathrm{mmol} \mathrm{m}^{-2} \mathrm{~d}^{-1}\right)$} \\
\hline & & $\begin{array}{r}\text { TOU } \\
\text { whole-core } \\
\text { incubation } \\
(n=4)\end{array}$ & $\begin{array}{r}\mathrm{CH}_{4} \\
\text { whole-core } \\
\text { incubation } \\
(n=4)\end{array}$ & $\begin{array}{r}\mathrm{CH}_{4} \\
\text { Diffusive flux to } \\
\text { sediment surface } \\
(n=1)\end{array}$ & $\begin{array}{r}\mathrm{CH}_{4} \\
\text { Diffusive flux } \\
\text { into SMTZ } \\
(n=1)^{2}\end{array}$ & $\begin{array}{r}\mathrm{SO}_{4}^{2-} \\
\text { Diffusive flux } \\
\text { into sediment } \\
(n=1)\end{array}$ & $\begin{array}{r}{ }^{35} \mathrm{~S} \text {-SRR integrated } \\
\text { over } \mathrm{AOM}^{3} \text { zone } \\
(n=3)\end{array}$ & $\begin{array}{r}\text { Integrated }{ }^{35} \text { S-SRR } \\
(n=3)\end{array}$ \\
\hline \multirow[t]{4}{*}{ B1 } & April 2012 & $19.7 \pm 2.5$ & $-0.10 \pm 0.05$ & -0.1 & & 0.4 & no AOM zone ${ }^{4}$ & $2.3 \pm 0.6$ \\
\hline & August 2012 & $22.5 \pm 2.9$ & $-1.2 \pm 0.6$ & $-(0.01)$ & & 0.8 & no AOM zone 4 & $0.5 \pm 0.1$ \\
\hline & October 2012 & $21.1 \pm 2.7$ & No data & -0.3 & & 1.4 & no AOM zone ${ }^{4}$ & $2.0 \pm 0.0 .5$ \\
\hline & February 2013 & $12.0 \pm 1.5$ & $-0.1 \pm 0.05$ & -0.02 & & 0.2 & no AOM zone ${ }^{4}$ & $2.2 \pm 0.6$ \\
\hline \multirow[t]{5}{*}{ H6 } & April 2012 & $33.5 \pm 3.5$ & $-0.3 \pm 0.1$ & -1.7 & -2.8 & 2.6 & $(10-18 \mathrm{~cm})$ & $11.6 \pm 2.9$ \\
\hline & April 2013 & & $-3.9 \pm 0.7^{1}$ & & & & $=-2.8 \pm 0.7$ & \\
\hline & August 2012 & $26.9 \pm 2.8$ & $-19.9 \pm 7.8^{5}$ & -2.3 & -2.6 & 2.7 & $\begin{array}{r}(10-18 \mathrm{~cm})= \\
-2.8 \pm 0.7\end{array}$ & $11.7 \pm 2.9$ \\
\hline & October 2012 & $25.9 \pm 2.7$ & -1.0 & -2.0 & -1.9 & 2.6 & $\begin{array}{r}(10-18 \mathrm{~cm})= \\
-2.4 \pm 0.6\end{array}$ & $11.5 \pm 2.9$ \\
\hline & February 2013 & $14.9+1.6$ & -1.1 & -0.5 & -0.4 & 1.3 & no AOM zone ${ }^{3}$ & $9.2 \pm 2.3$ \\
\hline
\end{tabular}

sel during sampling in rough seas into an area underlain by neighboring glacial clays with low pore-water methane concentrations. Excluding the August data, methane concentrations were low and between 1 and $10 \mu \mathrm{M}$ to a depth of 6,2 , and $6 \mathrm{~cm}$ in April, October, and February, respectively, before they increased sharply. At station H6, the highest and lowest concentrations in the cored depth interval were 5.7 and $1.5 \mathrm{mM}$, and they were recorded in August and February 2013, respectively. At this station, the methane concentrations generally increased linearly from the surface down to $10 \mathrm{~cm}$ depth. Below this depth they only increased slightly or remained constant.

Sulfate concentration gradients changed between the different seasons at both stations, reflecting changes in sulfate reduction rates over the observation period. At both stations, the sulfate concentration gradients were steepest in the topmost $8-10 \mathrm{~cm}$ in August, intermediate in April and October, and lowest in February, indicating highest and lowest sulfate reduction rates in late summer and winter, respectively (Fig. 2a-h). At station B1, sulfate was never consumed completely and concentrations remained above $1.5 \mathrm{mM}$ at the bottom of the core. In August and October, a distinct decrease in the sulfate concentration gradient occurred at around $8-10 \mathrm{~cm}$ depth. Despite some variability in the sulfate concentration profiles, the sulfate concentrations at the bottom of the core were similar during all observation periods. At station H6, sulfate always reached minimum detection concentrations of less than $100 \mu \mathrm{M}$ in the cored sediment interval, albeit at a substantially greater depth in February. The initial depth at which sulfate reached the lowest concentration from the surface down was defined as the initial minimum sulfate concentration depth, which occurred at $16 \mathrm{~cm}$ in April, $10 \mathrm{~cm}$ in August, $14 \mathrm{~cm}$ in October, and $25 \mathrm{~cm}$ in February.

\section{$3.3 \quad{ }^{35} \mathrm{~S}$-sulfate reduction rates}

At station B1, the depth-integrated SRR over the total core length varied from 0.5 to $2.3 \mathrm{mmol} \mathrm{m}^{2} \mathrm{~d}^{-1}$. The depthresolved SRR ranged from $63 \mathrm{nmol} \mathrm{cm}^{-3} \mathrm{~d}^{-1}$ at the sediment surface to $0.2 \mathrm{nmol} \mathrm{cm}^{-3} \mathrm{~d}^{-1}$ at the bottom of the cored intervals (Fig. 3a-h, Table 2). Contrary to expectations, the lowest SRRs were measured in August, which was possibly also due to the fact that the vessel drifted into a glacial clay area. The highest SRRs were measured in the topmost $2 \mathrm{~cm}$, with the exception of October 2012, when the maximum was found at $3 \mathrm{~cm}$ depth. Below the depth of maximum SRR, rates decreased exponentially, indicating that organoclastic sulfate reduction dominated and that the reactivity of the degrading organic material decreased exponentially with depth. More than $90 \%$ of the integrated sulfate reduction took place in the top $15 \mathrm{~cm}$ of sediment (Fig. 5a-d). Over the cored sediment interval, there was no peak that could be attributed to significant AOM. Nevertheless, the distinct curvature of the methane concentration profile in February 2013 at station B1 suggests that methane was oxidized in the sulfate reduction zone and that some of the sulfate reduction may have been coupled to anaerobic methane oxidation.

At station H6, depth-integrated SRR over the total core length varied from 9.2 to $11.7 \mathrm{mmol} \mathrm{m}^{-2} \mathrm{~d}^{-1}$. The highest measured SRR was $338 \mathrm{nmol} \mathrm{cm}^{-3} \mathrm{~d}^{-1}$ and occurred at $2 \mathrm{~cm}$ depth in April 2012. Organoclastic sulfate reduction dominated the interval down to $10 \mathrm{~cm}$. In April, August, and October 2012 two distinct sulfate reduction rate peaks were found at station H6: one at the surface and a second peak 

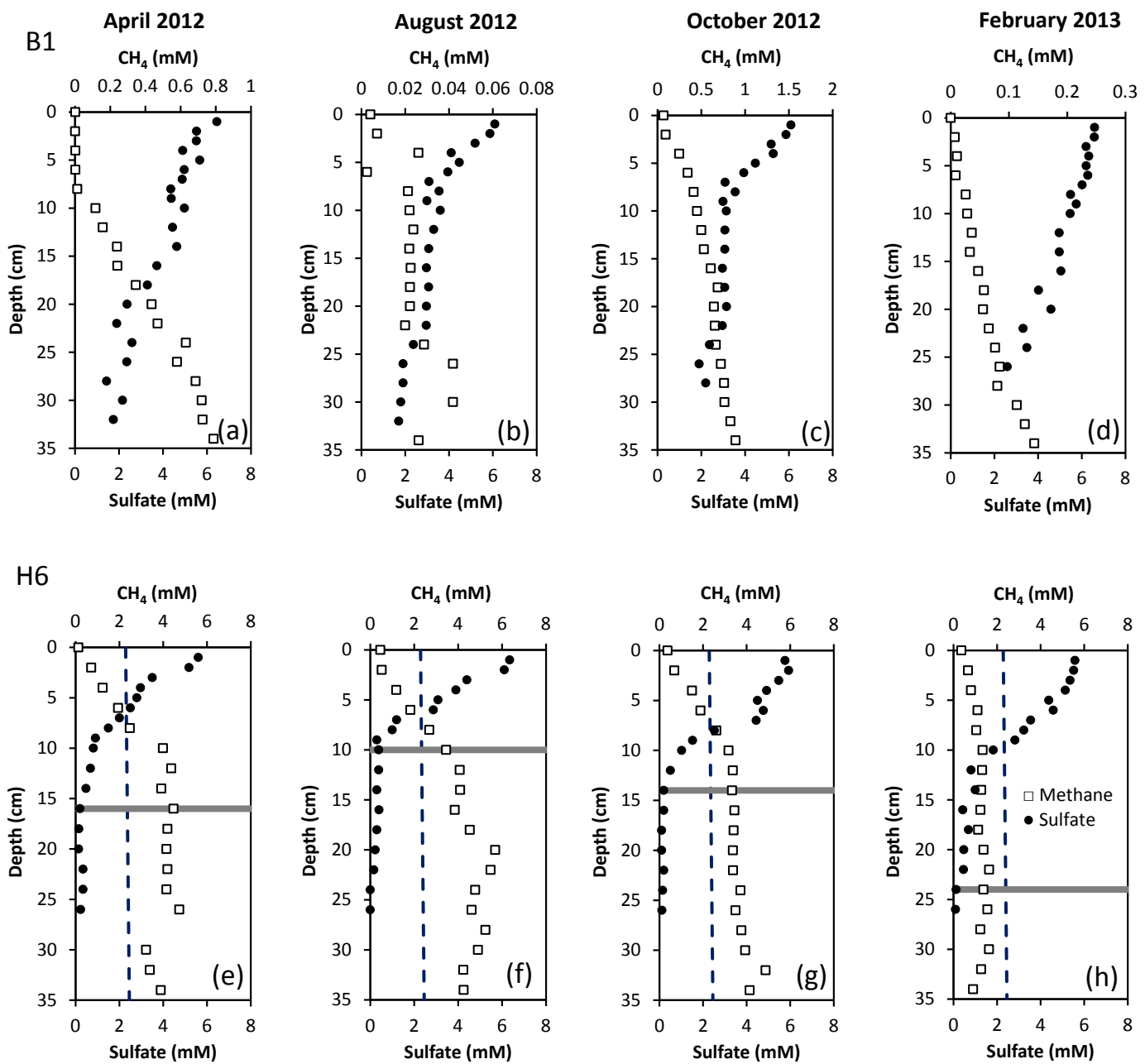

Figure 2. Pore-water profiles of total methane and sulfate at station B1 (a-d) and station H6 (e-h) for the different sampling periods. The grey line marks the initial minimum sulfate concentration depth. Dashed lines indicate the methane saturation concentration at 1 atm pressure (grey) at the time of sampling. All concentrations of methane are below the in situ saturation concentration of methane (see text for details).

between 10 and $18 \mathrm{~cm}$ depth. The latter peak covers the sulfate-methane transition zone and indicates that in this depth interval the rates of anaerobic methane oxidation coupled to sulfate reduction exceeded organoclastic sulfate reduction rates. We therefore defined the depth interval near the minimum sulfate concentration depth together with elevated SRR as the AOM zone (Table 2). Previous studies at nearby station $\mathrm{H} 5$ in Himmerfjärden also found AOM to be present at depths between 6 and $16 \mathrm{~cm}$, which is in agreement with our findings (Thang et al., 2013; Wegener et al., 2012). The depth-integrated rates of SRR in the sulfate-methane transition zone at station $\mathrm{H} 6$ were relatively constant over the three observation periods and varied between 2.4 and $2.8 \mathrm{mmol} \mathrm{m}^{2} \mathrm{~d}^{-1}$ (Table 2). In February, however, when sulfate penetrated to $24 \mathrm{~cm}$ depth, sulfate reduction rates were about 2 times lower compared to the other months. The previously observed elevated rates between 10 and $18 \mathrm{~cm}$ depth were not visible, although another SRR peak was observed between 5 and $9 \mathrm{~cm}$ depth. However, the high concentrations of sulfate and low concentrations of methane in this depth interval in February make it unlikely that this peak is due to AOM. It is more likely that this peak is associated with organiclastic sulfate reduction because no change in the sulfate or methane gradients was observed at this depth. Some sulfate reduction was also detected below $18 \mathrm{~cm}$ depth at station H6 in April, August, and October. Since nonradioactive carrier sulfate was added to the ${ }^{35} \mathrm{~S}$-tracer during these incubations, these rates indicate potential sulfate reduction activity in the methanogenic zone (Leloup et al., 2009).

\subsection{Benthic exchange of oxygen, sulfate, and methane}

Rates of total oxygen uptake are summarized in Table 2 and shown for comparison in Fig. 4. Total oxygen uptake was lowest in February at both stations (B1: 12.0 \pm $1.5 \mathrm{mmol} \mathrm{m}^{-2} \mathrm{~d}^{-1}$ and H6: $\left.14.9 \pm 1.6 \mathrm{mmol} \mathrm{m}^{-2} \mathrm{~d}^{-1}\right)$ and 

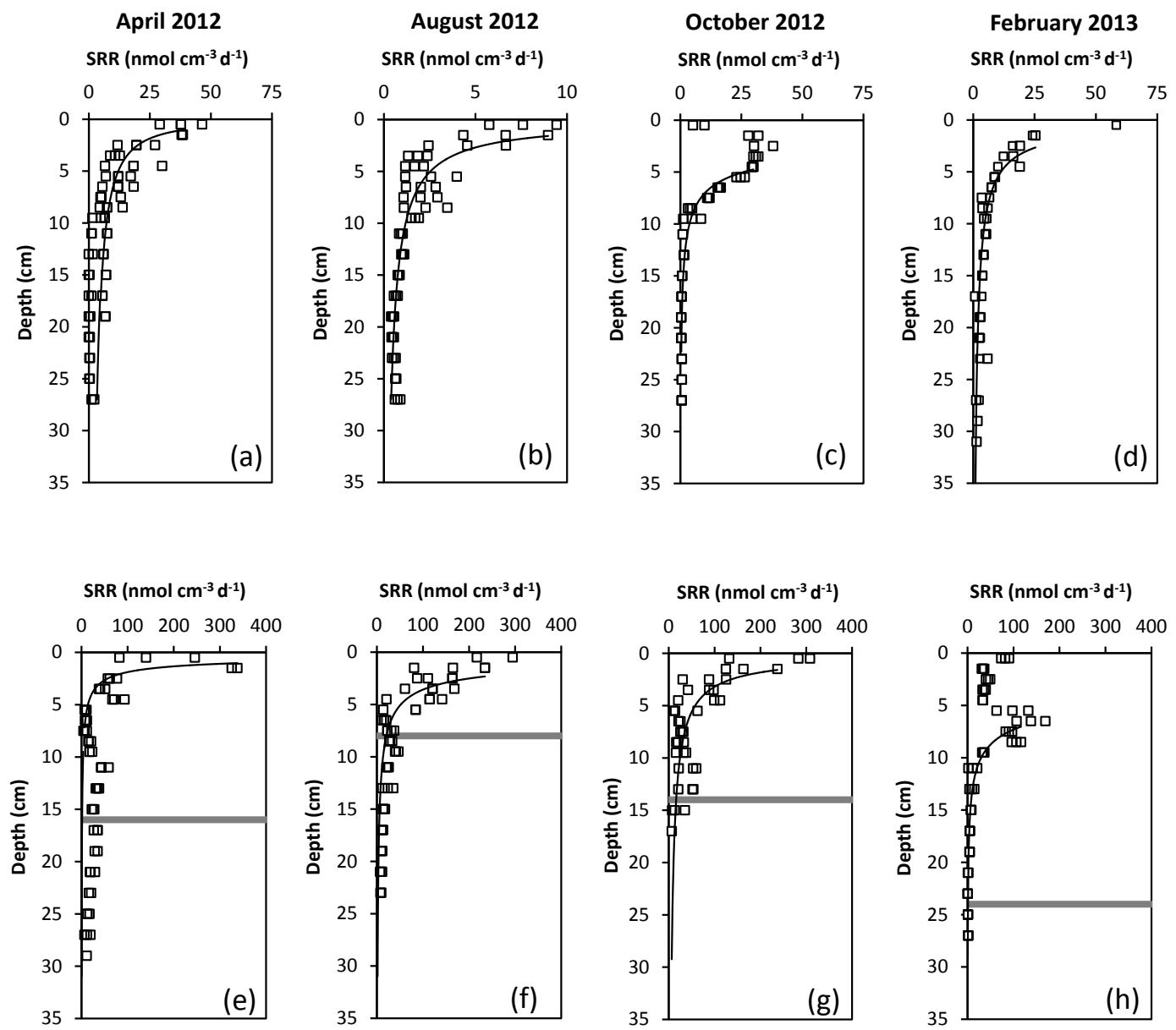

Figure 3. Depth gradients of bacterial sulfate reduction rates (SRRs) measured with ${ }^{35}$ S-sulfate at station B1 (a-d) and station H6 (e-h) for the different sampling periods. Black lines show the regression results to an exponential function of the form $y=a x^{-b}$. The grey line marks the initial minimum sulfate concentration depth.

highest in August at station B1 $\left(22.5 \pm 2.9 \mathrm{mmol} \mathrm{m}^{-2} \mathrm{~d}^{-1}\right)$ and in April at station H6 $\left(33.5 \pm 3.5 \mathrm{mmol} \mathrm{m}^{-2} \mathrm{~d}^{-1}\right)$. Diffusive fluxes of sulfate from the water column into the sediment ranged from $0.2 \mathrm{mmol} \mathrm{m}^{-2} \mathrm{~d}^{-1}$ in February to 1.4 mmol $\mathrm{m}^{-2} \mathrm{~d}^{-1}$ in October at station B1, and they ranged from $1.3 \mathrm{mmol} \mathrm{m}^{-2} \mathrm{~d}^{-1}$ in February to $2.7 \mathrm{mmol} \mathrm{m}^{-2} \mathrm{~d}^{-1}$ in August at station H6 (Table 2). These rates are significantly lower than the depth-integrated radiotracer rates and indicate that sulfate is reoxidized below the sediment surface by reaction with reactive iron (Thang et al., 2013). Wholecore methane fluxes ranged from $-0.1 \pm 0.05 \mathrm{mmol} \mathrm{m}^{-2} \mathrm{~d}^{-1}$ (February) to $-1.2 \pm 0.6 \mathrm{mmol} \mathrm{m}^{-2} \mathrm{~d}^{-1}$ (August) at station $\mathrm{B} 1$ and from $-0.3 \pm 0.1 \mathrm{mmol} \mathrm{m}^{-2} \mathrm{~d}^{-1}$ (April 2012) to $-19.9 \pm 7.8 \mathrm{mmol} \mathrm{m}^{-2} \mathrm{~d}^{-1}$ (August) at station H6 (Fig. 5, Table 2). However, the following year a significantly higher methane flux of $3.9 \mathrm{mmol} \mathrm{m}^{-2} \mathrm{~d}^{-1}$ was measured in April 2013 at station H6. Significant upward diffusive methane fluxes ranged from $0.02 \mathrm{mmol} \mathrm{m}^{-2} \mathrm{~d}^{-1}$ (February 2012) to $0.3 \mathrm{mmol} \mathrm{m}^{-2} \mathrm{~d}^{-1}$ (August) at station $\mathrm{B} 1$ and from 0.5 (February) to $2.3 \mathrm{mmol} \mathrm{m}^{-2} \mathrm{~d}^{-1}$ (August) at station $\mathrm{H} 6$.
Thus, there was a generally poor agreement between wholecore and diffusive flux-derived methane fluxes. The large discrepancy between the August 2012 diffusive flux and wholecore flux is best explained by the fact that the cores were taken from sediments with different organic carbon contents. Since several Multi-Corer casts were taken per station and the vessel's positioning ability in strong winds was tens of meters at best, sediment heterogeneity can possibly explain this difference. The very high whole-core flux value measured in August 2012 at station H6 is likely due to ebullition during the incubation at ambient air pressure and oversaturation of the pore water with respect to atmospheric pressure.

\section{Discussion}

\subsection{Bottom-water temperature and salinity}

Correlations between biogeochemical rates and fluxes in bottom-water temperatures in Himmerfjärden between April 


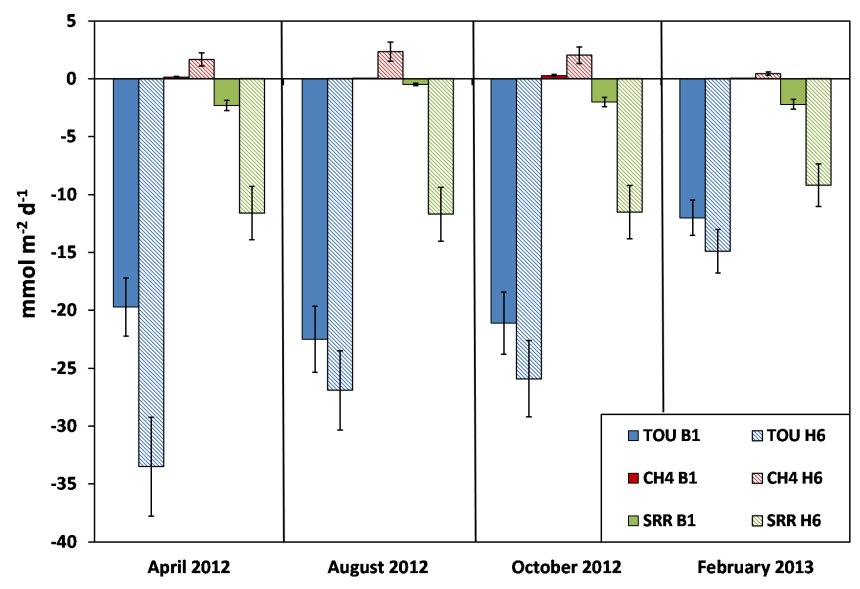

Figure 4. Comparison of benthic fluxes $\left(\mathrm{mmol} \mathrm{m}^{-2} \mathrm{~d}^{-1}\right)$ for sulfate $\left(\mathrm{SO}_{4}\right)$, methane $\left(\mathrm{CH}_{4}\right)$, and oxygen (TOU) for the different sampling periods.

2012 and February 2013 were weak for the period AprilOctober. Correlations were also forced by the low rates in the coldest observation period in early February 2013. All $R$ values calculated for pairs of temperature versus rate or flux were less than 0.2 and were not consistent for the fluxes of oxygen, methane, and sulfate indicating that additional environmental controlling factors played a role. It is likely that the microbial community involved in the cycling of methane and sulfur species in Himmerfjärden sediment is temperature-sensitive and that the low rates in February 2013 were due to the $3{ }^{\circ} \mathrm{C}$ temperature drop in bottom water from October 2012 to February 2013 (Table 1). This would be consistent with rate observations in comparable environments by Treude et al. (2005a), Abril and Iversen (2002), Crill and Martens (1983), and Westrich and Berner (1984) and is also supported by studies of the microbial community composition of estuarine sediments that showed variations as a function of temperature (e.g., Zhang et al., 2014). Regulation of methane fluxes largely by temperature implies that methane oxidation in Himmerfjärden sediment is less temperature-sensitive than methanogenesis, preventing methane-oxidizing bacteria from keeping up with the enhanced methane flux during summer. This requires significantly higher temperature stimulation of methanogenesis than methane oxidation, the lack of an electron acceptor, or successful competition for the same electron acceptor by organisms other than methane-oxidizing bacteria. Publications from lake environments and terrestrial environments suggest that aerobic methane-oxidizing bacteria may indeed be less temperature-sensitive than methanogens (King, 1992; Wik et al., 2014; Nguyen et al., 2011). However, this argument is not directly applicable to marine habitats. In the case of anaerobic methane oxidation, it is difficult to argue for a physiological temperature disadvantage of methane oxidizers compared to methanogens because of the tight coupling between sulfate reduction and methane oxidation, the phylogenetic proximity of ANME to known methanogenic Archaea (Knittel and Boetius, 2009), and similarities in membrane composition of ANME and methanogenic Archaea (Wegener et al., 2012). However, temperature control may not manifest itself by direct kinetic or bioenergetic regulation but indirectly through the influence on competing processes, e.g., sulfate reduction and methanogenesis. Furthermore, microbial community composition and biogeochemical rates often cannot be directly established from binary relationships with temperature since other physical and chemical parameters such as salinity, bottom-water oxygen concentrations, and organic carbon accumulation also vary seasonally. Of these, salinity is not considered to be important for the present study because the annual range in Himmerfjärden bottom water was only between 5.4 and $7 \%$, which is too small to affect the major electron acceptor and carbon degradation pathways.

\subsection{Effects of organic matter composition and sedimentation}

Organic carbon concentrations in Himmerfjärden are similar to other fjord- and fjärd-type estuarine sediments (Bianchi, 2007; Smith et al., 2015). Primary organic carbon export in Himmerfjärden varies strongly on both seasonal and interannual timescales (Blomqvist and Larsson, 1994). The major export periods occur during the spring phytoplankton bloom after ice breakup from March to April until early May, during a late-summer cyanobacterial bloom in August, and after a weaker, secondary phytoplankton bloom in September (Bianchi et al., 2002; Zakrisson and Larsson, 2014; Harvey et al., 2015). Terrestrial-derived organic carbon that is not derived from the sewage treatment plant plays only a minor role in this system because no major rivers enter the system and surface rainwater runoff is low. Based on sediment trap studies, the annual organic carbon flux in Himmerfjärden varies by more than an order of magnitude at station B1 and by about a factor of 3 in the inner parts of Himmerfjärden (Blomqvist and Larsson, 1994). Observations over a 5-year period by Blomqvist and Larsson (1994) indicate that primary organic carbon dominates organic sedimentation in the spring and summer at station B1, whereas station H6 is characterized by a spring dominance of primary carbon deposition but a much greater contribution of resuspended organic material to organic sedimentation during the fall (Blomqvist and Larsson, 1994).

A second effect to be considered is that stations B1 and H6 are located in bathymetric depressions. Station H6 is in the center of a subbasin separated from the outer Himmerfjärd by a sill (Fig. 1). Likewise, station B1 is located in a small depression at the head of a submarine channel that opens to the Baltic Sea. Fine-grained and reworked organicrich material preferentially accumulates in these depressions (Jonsson et al., 2003). Because of the importance of resuspended organic material for the vertical mass flux and bio- 

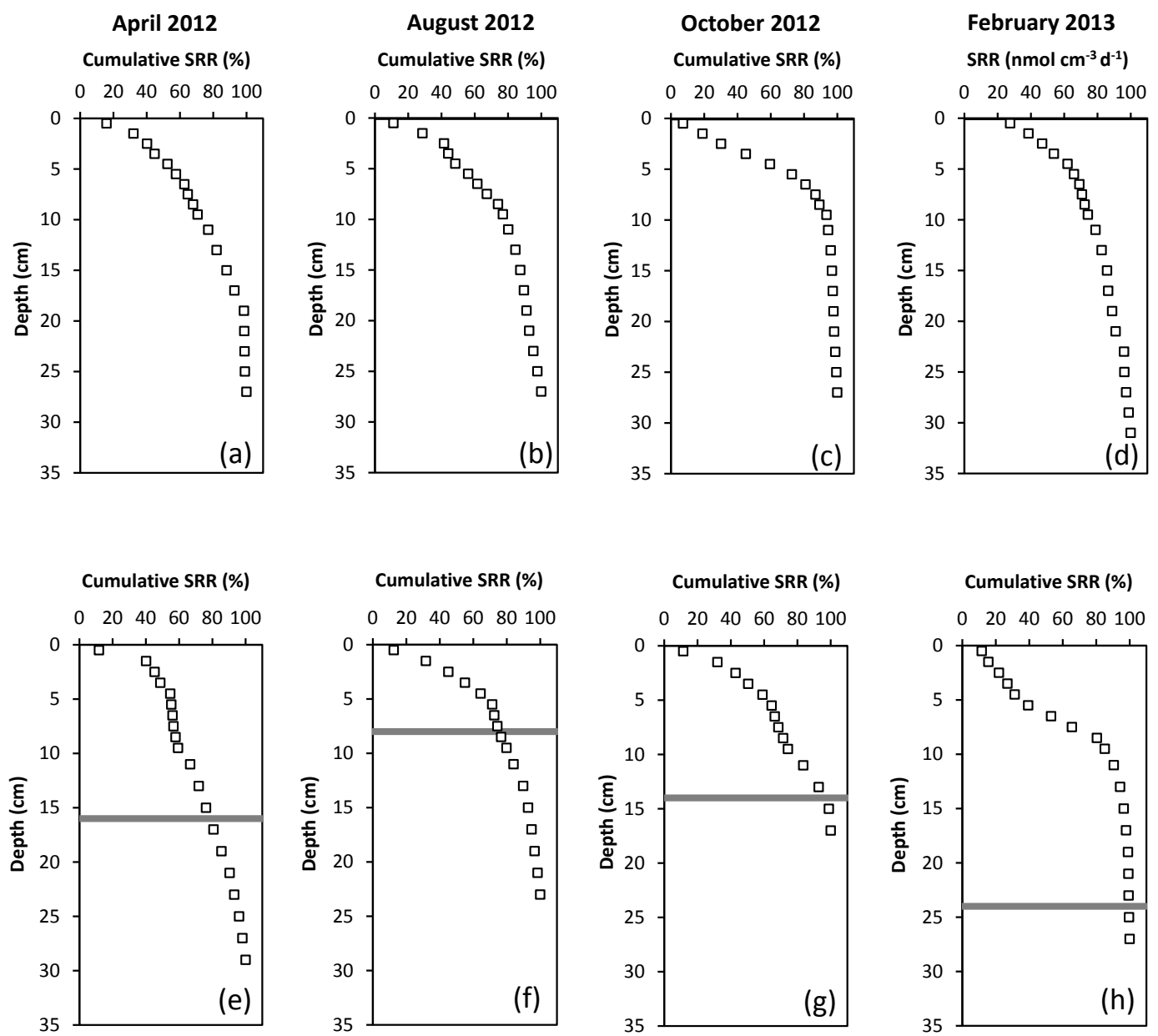

Figure 5. Depth distribution of sulfate reduction rate expressed as cumulative percentage at station B1 (a-d) and station H6 (e-h) for the different sampling periods. The grey line marks the initial minimum sulfate concentration depth.

turbation, the annual variability in the organic matter composition at the sediment surface varies year-round only between 5 and $6 \%$ OC with relatively constant $\mathrm{C} / \mathrm{N}$ ratios between 7.9 and 9.1 at station $\mathrm{B} 1$ and 8.3 and 9.2 at station H6 (Bonaglia et al., 2014). Organic mass accumulation rates in the accumulation bottoms based on ${ }^{210} \mathrm{~Pb}$ dating are reported between 3.3 and $9.5 \mathrm{~mol} \mathrm{~m}^{-2} \mathrm{yr}^{-1}$ (Thang et al., 2013; Karlsson et al., 2010). The combined effect of these sedimentation characteristics is that temporal variability in the settling primary organic carbon flux above the sediment surface is low, which reduces the overall temporal variability in organic carbon amount and composition and thereby in carbon mineralization rates. This small temporal variability is further influenced by macrofauna bioturbation in the top $2-3 \mathrm{~cm}$ of sediment in this area, foremost by the bivalve $\mathrm{Ma}$ coma balthica, the arthropod Pontoporeia femorata, and the polychaete Marenzelleria (Bonaglia et al., 2014). Although macrofauna is largely absent at station H6, sediment is also mixed at station $\mathrm{H} 6$ by bioturbating meiofauna (mostly ostracods) (Bonaglia et al., 2014).
The measured benthic oxygen uptake rates are consistent with the low variability in the surface organic carbon concentrations, $\mathrm{C} / \mathrm{N}$ ratios, and a temperature-dependent decrease in total oxygen uptake rates in winter. The slightly higher total oxygen uptake rate at station $\mathrm{H} 6$ is also consistent with the physiography of the enclosed small basin, favoring sediment trapping of fine material. In addition, the location of station H6 in the inner fjärd limits water exchange and leads to greater oxygen depletion, whereas the more open station B1 is affected by upwelling of oxygen-rich waters and comparatively less burial of organic material (Table 1).

\subsection{Methane fluxes, sulfate reduction, and methane oxidation}

Preferential accumulation of sediment in the bathymetric depressions of the inner Himmerfjärden results in very high sedimentation rates between 0.9 and $1.3 \mathrm{~cm} \mathrm{yr}^{-1}$ (Thang et al., 2013; Bianchi et al., 2002). In such sediments organic carbon burial and transfer of organic matter into the methanogenic zone is efficient and will occur within 20 to 
30 years. As a consequence of the low bottom-water salinity of $6 \%$ of the Baltic Sea at this latitude, seawater sulfate concentrations are less than $7 \mathrm{mM}$ and, by comparison with normal seawater, a comparatively lesser amount of organic matter can be degraded by bacterial sulfate reduction (Thang et al., 2013). Consequently, compared to normal marine sediments a larger proportion of organic matter undergoes anaerobic microbial degradation terminating in methanogenesis, which generates a high upward flux of methane into the sulfate-containing zone. Organiclastic sulfate-reducing bacteria will compete for the available sulfate with sulfate-reducing bacteria involved in the anaerobic oxidation of methane (Dale et al., 2006; Jørgensen and Parkes, 2010). Thermodynamic and kinetic constraints decide on the outcome between these two competing processes. Dale et al. (2006) suggested that due to lower winter temperatures and greater sulfate availability in the sulfate-methane transition zone in winter, the thermodynamic driving force for anaerobic methane oxidation increases, allowing for a greater proportion of anaerobic methane oxidation to be coupled to sulfate reduction in the winter. In the summer and fall, higher temperatures and sulfate limitation may favor organiclastic sulfate reduction and methanogenesis while limiting the anaerobic oxidation of methane. Most importantly, however, their analysis showed that due to thermodynamic constraints and slow growth rates of the methane-oxidizing archaea the microbial biomass does not change significantly over a year. These conceptual modeling results can be tested with our Himmerfjärden data.

Sulfate reduction rates, particularly at station H6, demonstrate how strongly bottom-water oxygen controls organic matter mineralization. In the spring, summer, and fall sulfate reduction was at its maximum in the first $2 \mathrm{~cm}$ of the sediments (Fig. 3e, f, g). In February, reduced organic carbon input and higher oxygen concentrations resulted in lower sulfate reduction rates and a downward displacement of the maximum rate sediment, which confined methane production to greater depths in the sediment.

The decrease in oxygen uptake matches well with the decrease in methane fluxes at the two stations in winter, which suggests an impact of oxygen on methane cycling (Table 2, Fig. 5). Higher oxygen levels enhance bioturbation and oxygen uptake by the abundant macro- and meiofauna (Norkko et al., 2015), but the mixing of sediment also affects methane transport to the water column, as the main transport process shifts from diffusion to advection. This effect is likely the main cause for the winter decrease in methane fluxes and concentrations. More aerated conditions indirectly enhance methane removal by sustaining aerobic methanotrophs (Valentine, 2011). It is plausible that since in other brackish coastal sediments, aerobic methanotrophs at the surface of Himmerfjärden sediments consume a significant part of upward-diffusing methane that was not oxidized by anaerobic methane oxidation (McDonald et al., 2005; Moussard et al., 2009; Treude et al., 2005a).
Published benthic methane fluxes for estuaries with similar salinities have a reported range of 0.002 to $0.25 \mathrm{mmol} \mathrm{m}^{-2} \mathrm{~d}^{-1}$ (Abril and Iversen, 2002; Martens and Klump, 1980; Sansone et al., 1998; Zhang et al., 2008; Borges and April, 2012; Martens et al., 1998). The methane fluxes derived from our core incubations (0.1$3.9 \mathrm{mmol} \mathrm{m}^{-2} \mathrm{~d}^{-1}$, ignoring the potentially biased value of $\left.19.9 \mathrm{mmol} \mathrm{m}^{-2} \mathrm{~d}^{-1}\right)$ and the corresponding diffusive fluxes (0.01-2.4 mmol m $\mathrm{m}^{-2} \mathrm{~d}^{-1}$ ) were high compared to these published fluxes. However, our fluxes are consistent with fluxes based on pore-water gradients by Thang et al. (2013) that were between 0.3 and $1.1 \mathrm{mmol} \mathrm{m}^{-2} \mathrm{~d}^{-1}$ at three nearby stations measured in May 2009.

A conspicuous property of all pore-water profiles at station H6, with the exception of the February 2013 sampling period, was the absence of a curvature in most methane concentration profiles, which would be expected for net methane oxidation by aerobic and anaerobic methane oxidation (Martens et al., 1998). Most concentration profiles of sulfate and methane at station H6 overlapped without a significant change in the methane concentration gradient. A similar observation had been made earlier for other Himmerfjärden sediments (Thang et al., 2013), as well as been reported for sediments of the northwestern Black Sea shelf (Knab et al., 2009) and in organic-rich shelf sediment of the Namibian upwelling system (Brüchert et al., 2009). Inefficient methane oxidation is also evident from the diffusive fluxes, which showed that the upward fluxes of methane into the sulfate-methane transition zone were only marginally higher than the methane fluxes to the sediment surface, indicating little attenuation of the methane flux in the sulfatemethane transition zone (Table 2). One possible explanation for this phenomenon is therefore that rates of sulfate reduction, coupled with anaerobic methane oxidation, except for the winter months, were low compared to the organiclastic sulfate reduction rate. An alternative explanation of our observations could be that the methane concentration gradients were affected by the presence of rising methane bubbles (Haeckel et al., 2007) or that bioturbation and bioirrigation linearized the concentration profiles (Dale et al., 2013). However, we do not favor these latter interpretations because of the absence of large macrofauna at station H6, the fact that methane concentrations were below the in situ saturation concentration of methane, and the fast pore-water methane sampling method that prevented significant gas formation.

An analysis of the cumulative distribution of ${ }^{35} \mathrm{~S}-\mathrm{SRR}$ with depth at station H6 provides clues to the proportion of organoclastic relative to anaerobic methane oxidationcoupled sulfate reduction at station H6 (Fig. 6e-h). In contrast to station B1, where an exponentially decreasing portion of sulfate reduction contributed to the total sulfate reduction at depth, at station $\mathrm{H6}$ a distinct steepening in the cumulative sulfate reduction is observed below $10 \mathrm{~cm}$ in April, August, and October. As discussed above, we do not attribute the steepening observed in February 2013 to the same pro- 
cess because sulfate was still present in abundance at this depth and methane concentrations were low and without any apparent change in gradient in this depth zone. The gradient in organoclastic sulfate reduction can be described by an exponential function (Jørgensen and Parkes, 2010),

$$
{ }^{35} \mathrm{SRR}=y z^{-b},
$$

where $z$ is depth $(\mathrm{cm})$ and $y$ and $b$ are regression coefficients (Jørgensen and Parkes, 2010). Fitting the sulfate reduction rates investigated here to such a function yielded exponential coefficients $b$ between 0.4 and 0.9 at station $\mathrm{B} 1$ and 0.3 and 0.8 at station H6 (Table 3). At station H6 the lowest coefficient was found for February 2013, when sulfate penetrated the deepest into the sediment (Table 3). Since the upward flux of methane provides an additional energy source to sulfatereducing bacteria, total sulfate reduction rates are expected to increase in the sulfate-methane transition zone. If substantial AOM-coupled and organiclastic sulfate reduction occur at the same depths, the total ${ }^{35} \mathrm{~S}$-sulfate reduction rate depth gradient will be lower and the exponential coefficient $b$ will be smaller than for a setting without significant AOM. The difference between the exponential coefficients for the different observation times can be used to calculate the variation in the contribution of AOM to the total sulfate reduction rate. At station H6, between 5\% (August 2012) and 20\% (April 2012) of the total sulfate reduction can be associated with anaerobic methane oxidation. A comparison of the method above with the ${ }^{35} \mathrm{~S}$-sulfate reduction rates integrated over the length of the $\mathrm{H} 6$ sediment cores with the rates integrated in the AOM zone also indicated that $>20 \%$ of sulfate reduction at station $\mathrm{H} 6$ was supported by anaerobic methane oxidation (Table 2). In near-shore continental margin sediments worldwide, the fraction of methane-driven sulfate reduction varies between locations and accounts for 3-40\% of total sulfate reduction, with $10 \%$ possibly representing a global mean value (Jørgensen and Kasten, 2006). The average 20\% contribution calculated here falls in the upper range of these values and is similar to values reported before for one of the monitoring stations within Himmerfjärden (Thang et al., 2013) and also for a very productive Chilean slope sediment (8$24 \%$ ) (Treude et al., 2005b). The good match between the upward fluxes of methane in the sulfate-methane transition zone and the measured sulfate reduction rates in the transition zone also indicate that other proposed electron acceptors for anaerobic methane oxidation such as iron are unimportant in these sediments (Beal et al., 2009; Egger et al., 2014).

\subsection{Temporal variability in hydrostatic pressure}

The abrupt decrease in pore-water methane concentrations from October 2012 to early February 2013 and the subsequent increase in April 2013 cannot be explained by variation in methane oxidation alone because the temporal change in pore-water methane concentration was large compared to the inferred methane oxidation rates based on fluxes in and
Table 3. Best-fit regression coefficients $a$ and $b$ for the depth gradient of sulfate reduction rates $\left({ }^{35} \mathrm{SRR}=a z^{-b}(z=\right.$ depth, $\left.\mathrm{cm})\right)$.

\begin{tabular}{llrr}
\hline Station & Sampling time & $\begin{array}{r}\text { Exponential } \\
\text { coefficient }(a)\end{array}$ & $\begin{array}{r}\text { Exponential } \\
\text { coefficient }(b)\end{array}$ \\
\hline B1 & April 2012 & 147.0 & -1.4 \\
& August 2012 & 11.7 & -0.9 \\
& October 2012 & 16.0 & -0.4 \\
& February 2013 & 33.5 & -0.8 \\
\hline H6 & April 2012 & 18.6 & -0.5 \\
& August 2012 & 37.4 & -0.5 \\
& October 2012 & 133.2 & -0.8 \\
& February 2013 & 25.0 & -0.4 \\
\hline
\end{tabular}

out of the AOM zone. In addition, except for downwarddiffusing sulfate, there was no other significant electron acceptor present at depth. It is unlikely that rates of methanogenesis would have decreased significantly between the fall and the winter and resumed again in the spring because of the sedimentological characteristics described above and the small difference in sediment temperatures for February and April (Table 1). Changes in organic matter sedimentation at the sediment surface also have no significant influence on methanogenesis rates in buried sediment and cannot explain the sudden decrease in methane concentration at depth. An alternative explanation for the changes in methane concentrations is required. A possible explanation could be that changes in upward transport of methane are due to variability in hydrostatic pressure and the associated diffusive and advective upward transport of methane from depth. The free gas depth of methane is thought to follow changes in hydrostatic pressure and temperature (Mogollón et al., 2011; Tóth et al., 2015). An estimated $10 \%$ of the fine-grained sediments in the Stockholm archipelago area are underlain by pockets of free methane (Persson and Jonsson, 2000) and these free gas pockets are preferentially located in areas with the thickest postglacial mud accumulation, generally in the center of the subbasins and along fault lineaments (Söderberg and Flodén, 1992). Based on sub-bottom echosounder profiling, the surface of the free gas zone in accumulation areas in Himmerfjärden and other areas of the Stockholm archipelago is between 1 and $3 \mathrm{~m}$ depth (Söderberg and Flodén, 1992). During low sea levels, the free gas zone is expected to migrate closer to the sediment surface, whereas during high sea levels the free gas zone is depressed into the sediment. The total variation in sea level is related to air pressure, prevailing wind directions, precipitation, and the balance of saltwater entry through the Danish straits and freshwater discharge from rivers entering the Baltic Sea (Andersson, 2002). Additional effects are caused by local coastal bathymetry, current flow, and possibly local submarine groundwater discharge. These multiple parameters result in complex subsurface hydrology and may produce sea level fluctuations that can be as much as 
$50 \mathrm{~cm}$, sufficient to explain the changes in methane concentrations observed here. Unfortunately, local data within Himmerfjärden on sea level fluctuations are not available for our respective sampling locations, and regional sea level stands should not be directly applied to the sample sites.

The discussion above demonstrates that a variety of processes interact in these fjord sediments to produce the observed methane fluxes. It is beyond the scope of this paper to develop a unifying model against which the variability of the observed fluxes can be tested, but we would like to point out that the local coastal hydrography and hydrogeology would need to be accounted for in such a coupled physical biogeochemical model. To our knowledge, sufficient subsurface geophysical data are not currently available to establish appropriate physical boundary conditions for such a model. Detailed geophysical analysis of the subsurface structure at high vertical resolution together with long-term monitoring of the pore-water chemistry would shed new light on the coupling between subsurface hydrology and methane emissions.

\section{Conclusions}

A greater understanding of methane emissions from estuarine and coastal sediments is important to estimate the contribution of these environments to global marine methane fluxes. High benthic fluxes of methane from these sediments showed that total methane oxidation was relatively inefficient, despite the fact that anaerobic methane oxidation contributed up to $20 \%$ to total sulfate reduction. Of the different environmental regulators, bottom-water oxygen had the strongest influence for the regulation of methane emissions. Oxygen availability directly enhanced aerobic organic matter mineralization by shifting the redox cascade in the sediments and indirectly by stimulating meiofauna and macrofauna activity, thereby stimulating both the aerobic carbon mineralization and oxidative recycling of sulfate. The annual variability in sediment methane concentrations and benthic methane fluxes indicates that the annual environmental changes at these near-shore, but relatively deep-water, localities are considerable. Very few data on sediment biogeochemical processes are currently available for aerobic and anaerobic carbon mineralization and methane cycling during winter months when ice cover inhibits access and sampling. Process rates inferred from sampling during open-water conditions over the whole year are therefore likely overestimates.

Hydrostatic pressure changes and complex subsurface hydrological conditions may also affect the temporal variability of subsurface methane concentrations. The spatial and temporal variability of these conditions must also be considered as an important component for understanding methane emissions from near-shore coastal and estuarine waters.

\section{Data availability}

The data are available from the second author upon request.

Author contributions. Joanna E. Sawicka conducted the sampling and analysis for the study and wrote the paper. Volker Brüchert devised the study, interpreted the data, created the figures and tables, and wrote the paper.

Competing interests. The authors declare that they have no conflict of interest.

Acknowledgement. We are grateful to the staff of Askö Laboratory for their help and cooperation during the cruises and our stays on the island of Askö. We would like to thank Barbara Deutsch, Camilla Olsson, and Stefano Bonaglia for their help during sampling. The study was funded by the grant from the Bolin Centre for Climate Research, Baltic Ecosystem Adaptive Management $(B E A M)$ and the EU BONUS+ project Baltic Gas. We acknowledge the comments by the two reviewers that substantially improved the paper.

Edited by: T. Treude

Reviewed by: two anonymous referees

\section{References}

Abril, G. and Iversen, N.: Methane dynamics in a shallow non-tidal estuary (Randers Fjord, Denmark), Mar. Ecol.-Prog. Ser., 230, 171-181, 2002.

Amouroux, D., Roberts, G., Rapsomanikis, S., and Andreae, M. O.: Biogenic gas $\left(\mathrm{CH}_{4}, \mathrm{~N}_{2} \mathrm{O}\right.$, DMS $)$ emission to the atmosphere from near-shore and shelf waters of the North-western Black Sea, Estuar. Coast. Shelf S., 54, 575-587, 2002.

Andersson, H. C.: Influence of long-term regional and large-scale atmospheric circulation on the Baltic sea level, Tellus A, 54, 76$88,2002$.

Bange, H. W., Bergmann, K., Hansen, H. P., Kock, A., Koppe, R., Malien, F., and Ostrau, C.: Dissolved methane during hypoxic events at the Boknis Eck time series station (Eckernförde Bay, SW Baltic Sea), Biogeosciences, 7, 1279-1284, doi:10.5194/bg7-1279-2010, 2010.

Beal, E. J., House, C. H., and Orphan, V. J.: Manganese- and IronDependent Marine Methane Oxidation, Science, 325, 184-187, 2009.

Bianchi, T. S.: Biogeochemistry of Esturaries, Oxford University Press, Oxford New York, 2007.

Bianchi, T. S., Engelhaupt, E., McKee, B. A., Miles, S., Elmgren, R., Hajdu, S., Savage, C., and Baskaran, M.: Do sediments from coastal sites accurately reflect time trends in water column phytoplankton? A test from Himmerfjärden Bay (Baltic Sea proper), Limnol. Oceanogr., 47, 1537-1544, 2002.

Blomqvist, S. and Larsson, U.: Detrital bedrock elements as tracers of settling resuspended particulate matter in a coastal area of the Baltic Sea, Limnol. Oceanogr., 39, 880-896, 1994. 
Bonaglia, S., Deutsch, B., Bartoli, M., Marchant, H. K., and Brüchert, V.: Seasonal oxygen, nitrogen and phosphorus benthic cycling along an impacted Baltic Sea estuary: regulation and spatial patterns, Biogeochemistry, 119, 1-22, 2014.

Borges, A. V. and Abril, G.: Carbon Dioxide and Methane Dynamics in Estuaries, in: Treatise on Estuarine and Coastal Science, edited by: Wolanski, E. and McLusky, D., Academic Press, Waltham, 119-161, 2011.

Boudreau, B. P.: Diagenetic models and their implementation, Springer Verlag, Berlin Heidelberg, 1996.

Brüchert, V., Currie, B., and Peard, K.: Hydrogen sulphide and methane emissions on the central Namibian shelf, Progr. Oceanogr., 83, 169-179, 2009.

Crill, P. M. and Martens, C. S.: Spatial and temporal fluctuations of methane production in anoxic coastal marine sediments, Limnol. Oceanogr., 6, 1117-1130, 1983.

Dale, A. W., Regnier, P., and Van Cappellen, P.: Bioenergetic Controls on Anaerobic Oxidation of Methane (AOM) in Coastal Marine Sediments: A Theoretical Analysis, Am. J. Sci., 306, 246294, 2006.

Dale, A. W., Bertics, V. J., Treude, T., Sommer, S., and Wallmann, K.: Modeling benthic-pelagic nutrient exchange processes and porewater distributions in a seasonally hypoxic sediment: evidence for massive phosphate release by Beggiatoa?, Biogeosciences, 10, 629-651, doi:10.5194/bg-10-629-2013, 2013.

Egger, M., Rasigraf, O., Sapart, C. J., Jilbert, T., Jetten, M. S. M., and Röckmann, T.: Iron-mediated anaerobic oxidation of methane in brackish coastal sediments, Environ. Sci. Technol., 49, 277-283, 2014.

Elmgren, R. and Larsson, U.: Himmerfjärden: förändringar i ett näringsbelastat kustekosystem i Östersjön, Reports of the Swedish Environmental Protection Agency, Stockholm, Sweden, 1997.

Etiope, G., Lassey, K. R., Klusman, R. W., and Boschi, E.: Reappraisal of the Fossil Methane Budget and Related Emission from Geologic Sources, Geophys. Res. Lett., 35, doi:10.1029/2008g1033623, 2008.

Haeckel, M., Boudreau, B. P., and Wallmann, K.: Bubble-induced porewater mixing: A 3-D model for deep porewater irrigation, Geochim. Cosmochim. Ac., 71, 5135-5154, 2007.

Harvey, E. T., Kratzer, S., and Philipson, P.: Satellite-based water quality monitoring for improved spatial and temporal retrieval of chlorophyll-a in coastal waters, Remote Sens. Environ., 158, 417-430, 2015.

Iversen, N. and Jørgensen, B. B.: Diffusion coefficients of sulfate and methane in marine sediments: Influence of porosity, Geochim. Cosmochim. Ac., 57, 571-578, 1994.

Jonsson, P., Persson, J., and Holmberg, P.: Skärgårdens bottnar, Report of the Swedish Environmental Protection Agency, Stockholm, No. 5212, 114, 2003.

Jørgensen, B. B.: A comparison of methods for the quantification of bacterial sulfate reduction in coastal marine sediments, Geomicrobiol. J., 1, 11-27, 1978.

Jørgensen, B. B. and Kasten, S.: Sulfur Cycling and Methane Oxidation, in: Marine Geochemistry, edited by: Schulz, H. and Zabel, M., Springer, Berlin Heidelberg, 271-309, 2006.

Jørgensen, B. B. and Parkes, R. J.: Role of sulfate reduction and methane production by organic carbon degradation in eutrophic fjord sediments (Limfjorden, Denmark), Limnol. Oceanogr., 55, 1338-1352, 2010.

Judd, A. G.: Natural seabed gas seeps as sources of atmospheric methane, Environ. Geol., 46, 988-996, 2004.

Kallmeyer, J., Ferdelman, T. G., Weber, A., Fossing, H., and Jørgensen, B. B.: Evaluation of a cold chromium distillation procedure for recovering very small amounts of radiolabeled sulfide related to sulfate reduction measurements, Limnol. Oceanogr.Meth., 2, 171-180, 2004.

Kampbell, D. H., Wilson, J. T., and Vandegrift, S. A.: Dissolved Oxygen and Methane in Water by a GC Headspace Equilibration Technique, Intern. J. Environ. An. Ch., 36, 249-257, 1989.

Karlsson, M., M. Malmaeus, M., Rydin, E., and Jonsson, P.: Bottenundersökningar i Upplands, Stockholms, Södermanlands och Östergötlands skärgårdar: 2008-2009, Svenska Miljöinstitut, B1928, 102, 2010.

King, G. M.: Ecological Aspects of Methane Oxidation, a Key Determinant of Global Methane Dynamics, in: Advances in Microbial Ecology, 12, edited by: Marshall, K. C., 431-468, 1992.

Kirschke, S., Bousquet, P., Ciais, P., Saunois, M., Canadell, J. G., Dlugokencky, E. J., Bergamaschi, P., Bergmann, D., Blake, D. R., and Bruhwiler, L.: Three Decades of Global Methane Sources and Sinks, Nat. Geosci., 6, 813-823, 2013.

Knab, N. J., Cragg, B. A., Borowski, C., Parkes, R. J., Pancost, R., and Jørgensen, B. B.: Anaerobic oxidation of methane (AOM) in marine sediments from the Skagerrak (Denmark): I. Geochemical and microbiological analyses, Geochim. Cosmochim. Ac., 72, 2868-2879, 2009.

Knittel, K. and Boetius, A.: Anaerobic Oxidation of Methane: Progress with an Unknown Process, Annu. Rev. Microbiol., 63, 311-334, 2009.

Kristensen, E., Bouillon, S., Dittmar, T., and Marchand, C.: Organic carbon dynamics in mangrove ecosystems: A review, Aquat. Bot., 89, 201-219, 2008.

Larsson, U., Nyberg, U., Höglander, H., Sjösten, A., Sandberg, M., and Walve, J.: Himmerfjärdens miljörapport 2012, Department of Ecology, Environment, and Plant Sciences, Technical Report 50, 75, 2012.

Leloup, J., Fossing, H., Kohls, K., Holmkvist, L., Borowski, C., and Jørgensen, B. B.: Sulfate-reducing bacteria in marine sediment (Aarhus Bay, Denmark): abundance and diversity related to geochemical zonation, Environ. Microbiol., 11, 1278-1291, 2009.

Martens, C. S. and Berner, R. A.: Methane production in the interstitial waters of sulfate-depleted marine sediments, Science, 185 , 1167-1169, 1974.

Martens, C. S. and Klump, J. V.: Biogeochemical cycling in an organic-rich coastal marine basin. 4. An organic carbon budget for sediments dominated by sulfate reduction and methanogenesis, Geochim. Cosmochim. Ac., 48, 1987-2004, 1984.

Martens, C. S., Albert, D. B., and Alperin, M. J.: Biogeochemical processes controlling methane in gassy coastal sediments - Part 1. A model coupling organic matter flux to gas production, oxidation, and transport, Cont. Shelf Res., 18, 1741-1770, 1998.

Martens, C. S. and Klump, J. V.: Biogeochemical cycling in an organic-rich coastal marine basin - I. Methane sediment-water exchange processes, Geochim. Cosmochim. Ac., 44, 471-490, 1980. 
Marty, D., Bonin, P., Michotey, V., and Bianchi, M.: Bacterial biogas production in coastal systems affected by freshwater inputs, Cont. Shelf Res., 21, 2105-2115, 2001.

McDonald, I. R., Smith, K., and Lidstrom, M. E.: Methanotrophic populations in estuarine sediment from Newport Bay, California, FEMS Microbiol. Lett., 250, 287-293, 2005.

Middelburg, J., Nieuwenhuize, J., Iversen, N., Høgh, N., de Wilde, H., Helder, W., Seifert, R., and Christof, O.: Methane distribution in European tidal estuaries, Biogeochemistry, 59, 95-119, 2002.

Mogollón, J. M., Dale, A. W., L'Heureux, I., and Regnier, P.: Impact of seasonal temperature and pressure changes on methane gas production, dissolution, and transport in unfractured sediments, J. Geophys. Res.-Biogeo., 116, G03031, doi:10.1029/2010jg001592, 2011.

Moussard, H., Stralis-Pavese, N., Bodrossy, L., Neufeld, J. D., and Murrell, J. C.: Identification of active methylotrophic bacteria inhabiting surface sediment of a marine estuary, Environ. Microbiol. Repts., 1, 424-433, 2009.

Musenze, R. S., Werner, U., Grinham, A., Udy, J., and Yuan, Z.: Methane and nitrous oxide emissions from a subtropical estuary (the Brisbane River estuary, Australia), Sci. Total Environ., 472, 719-729, 2014.

Nguyen, T. D., Crill, P., and Bastviken, D.: Implications of temperature and sediment characteristics on methane formation and oxidation in lake sediments, Biogeochemistry, 100, 185-196, 2010.

Norkko, J., Gammal, J., Hewitt, J., Josefson, A., Carstensen, J., and Norkko, A.: Seafloor Ecosystem Function Relationships: In Situ Patterns of Change Across Gradients of Increasing Hypoxic Stress, Ecosystems 18, 1424-1439, 2015.

Persson, J. and Jonsson, P.: Historical development of laminated sediments-an approach to detect soft sediment ecosystem changes in the Baltic Sea, Mar. Poll. Bull., 40, 122-134, 2000.

Reeburgh, W. S.: Oceanic Methane Biogeochemistry, Chem. Rev., 107, 486-513, 2007.

Reindl, A. R. and Bolałek, J.: Methane flux from sediment into nearbottom water and its variability along the Hel Peninsula - Southern Baltic, Sea, Cont. Shelf Res., 74, 88-93, 2014.

Savage, C., Leavitt, P. R., and Elmgren, R.: Effects of land use, urbanization, and climate variability on coastal eutrophication in the Baltic Sea, Limnol. Oceanogr., 55, 1033-1046, 2010.

Sansone, F. J., Rust, T. M., and Smith, S. V.: Methane Distribution and Cycling in Tomales Bay, California, Estuaries, 21, 66-77, 1998.

Sansone, F. J., Holmes, M. E., and Popp, B. N.: Methane stable isotopic ratios and concentrations as indicators of methane dynamics in estuaries, Global Biogeochem. Cy., 13, 463-474, 1999.

Seeberg-Elverfeldt, J., Schlüter, M., Feseker, T., and Kölling, M.: Rhizon sampling of porewaters near the sediment-water interface of aquatic systems, Limnol. Oceanogr.-Meth., 3, 361-371, 2005.

Smith, R. W., Bianchi, T. S., Allison, M., Savage, C., and Galy, V.: High rates of organic carbon burial in fjord sediments globally, Nat. Geosci., 8, 450-453, 2015.

Söderberg, P. and Flodén, T.: Gas seepages, gas eruptions and degassing structures in the seafloor along the Strömma tectonic lineament in the crystalline Stockholm Archipelago, east Sweden. Cont. Shelf Res., 12, 1157-1171, 1992.
Stridh, S.: SYVAB Himmerfjärdsverket Miljörapport 2012, www.syvab.se/information/dokument/syvabs-miljorapporter, 53, 2012.

Thang, N., Brüchert, V., Formolo, M., Wegener, G., Ginters, L., Jørgensen, B. B., and Ferdelman, T.: The Impact of Sediment and Carbon Fluxes on the Biogeochemistry of Methane and Sulfur in Littoral Baltic Sea Sediments (Himmerfjärden, Sweden), Estuar. Coast., 36, 98-115, 2013.

Tóth, Z., Spiess, V., and Keil, H.: Frequency dependence in seismoacoustic imaging of shallow free gas due to gas bubble resonance, J. Geophys. Res.-Sol. Ea., 120, 8056-8072, 2015.

Treude, T., Krüger, M., Boetius, A., and Jørgensen, B. B.: Environmental control on anaerobic oxidation of methane in the gassy sediments of Eckernförde Bay (German Baltic), Limnol. Oceanogr., 50, 1771-1786, 2005a.

Treude, T., Niggemann, J., Kallmeyer, J., Wintersteller, P., Schubert, C. J., Boetius, A., and Jørgensen, B. B.: Anaerobic oxidation of methane and sulfate reduction along the Chilean continental margin, Geochim. Cosmochim. Ac., 69, 2767-2779, 2005 b.

Upstill-Goddard, R. C., Barnes, J., Frost, T., Punshon, S., and Owens, N. J. P.: Methane in the southern North Sea: Low-salinity inputs, estuarine removal, and atmospheric flux, Global Biogeochem. Cy., 14, 1205-1217, 2000.

Valentine, D. L.: Emerging Topics in Marine Methane Biogeochemistry, Annual Rev. Mar. Sci., 3, 147-171, 2011.

Wegener, G., Bausch, M., Holler, T., Thang, N. M., Prieto Mollar, X., Kellermann, M. Y., Hinrichs, K. U., and Boetius, A.: Assessing sub-seafloor microbial activity by combined stable isotope probing with deuterated water and ${ }^{13} \mathrm{C}$-bicarbonate, Environ. Microbiol., 14, 1517-1527, 2012.

Westrich, J. T. and Berner, R. A.: The role of sedimentary organic matter in bacterial sulfate reduction: The G model tested, Limnol. Oceanogr., 29, 236-249, 1984.

Wik, M., Thornton, B. F., Bastviken, D., MacIntyre, S., Varner, R. K., and Crill, P. M.: Energy input is primary controller of methane bubbling in subarctic lakes, Geophys. Res. Lett., 41, 555-560, 2014.

Wilhelm, E., Battino, R., and Wilcock, R. J.: Low-pressure solubility of gases in liquid water, Chem. Rev., 77, 219-262, 1977.

Zakrisson, A. and Larsson, U.: Regulation of heterocyst frequency in Baltic Sea Aphanizomenon sp., J. Plankton Res., 36, 13571367, 2014.

Zhang, G., Zhang, J., Liu, S., Ren, J., Xu, J., and Zhang, F.: Methane in the Changjiang (Yangtze River) estuary and its adjacent marine area: riverine input, sediment release and atmospheric fluxes, Biogeochemistry, 91, 71-84, 2008.

Zhang, W., Bougouffa, S., Wang, Y., Lee, O. O., Yang, J., Chan, C., Song, X., and Qian, P.-Y.: Toward understanding the dynamics of microbial communities in an estuarine system, PLoS ONE, 9, e94449, doi:10.1371/journal.pone.0094449, 2014. 